\title{
Profil Mean Arterial Pressure dan Tekanan Darah pada Pasien Hipertensi Krisis dengan Kombinasi Amlodipin
}

\author{
Ria Angelina, Nurmainah, Robiyanto \\ Program Studi Farmasi, Fakultas Kedokteran, Universitas Tanjungpura, Pontianak, Indonesia
}

\begin{abstract}
Abstrak
Berdasarkan pedoman pengobatan hipertensi krisis, pengobatan hipertensi emergensi menggunakan antihipertensi parenteral sedangkan hipertensi urgensi menggunakan antihipertensi oral. Tujuannya agar tercapai penurunan Mean Arterial Pressure (MAP) di bawah 25\% dan tekanan darah sistolik/diastolik (TDS/TDD) di bawah atau sama dengan 160/100 mmHg. Penelitian ini bertujuan untuk mendeskripsikan penurunan MAP dan TDS/TDD setelah 24 jam pemberian amlodipin oral dengan berbagai kombinasi pada pasien hipertensi krisis. Penelitian ini merupakan penelitian observasional dengan rancangan potong lintang (cross-sectional) yang bersifat deskriptif. Pengumpulan data dilakukan secara retrospektif berdasarkan data rekam medis pasien hipertensi krisis rawat inap di RSUD Sultan Syarif Mohamad Alkadrie Kota Pontianak periode Januari 2016-Desember 2017. Sampel yang diperoleh sebanyak 38 pasien. Hasil penelitian menunjukkan bahwa pasien hipertensi emergensi yang menggunakan amlodipin secara oral dengan kombinasi antihipertensi lainnya memiliki nilai MAP setelah 24 jam sebesar $24 \%$ dan beberapa pasien hipertensi emergensi menunjukkan pencapaian MAP-nya sebesar $32 \%$. Namun demikian, penurunan TDS/TDD setelah 24 jam mencapai di bawah atau sama dengan 160/100 $\mathrm{mmHg}$. Penggunaan amlodipin oral dengan berbagai kombinasi terapi antihipertensi lainnya pada pasien hipertensi urgensi menunjukkan pencapaian MAP berkisar 20-23\%. Sementara itu, TDS/TDD setelah 24 jam mencapai sekitar dan di bawah 160/100 mmHg. Penggunaan amlodipin secara oral dengan kombinasi antihipertensi lainnya pada pasien hipertensi emergensi belum mampu menunjukkan penurunan MAP sesuai yang diinginkan. Di sisi lain, penanganan hipertensi urgensi dengan menggunakan amlodipin oral dengan berbagai kombinasi terapi antihipertensi lainnya menunjukkan pencapaian penurunan MAP sesuai dengan pedoman pengobatan hipertensi krisis.
\end{abstract}

Kata kunci: Amlodipin, hipertensi krisis, mean arterial pressure, tekanan darah

\section{Mean Arterial Pressure and Blood Pressure Profile in Hypertensive Crises Patients with Amlodipine Therapy Combination}

\begin{abstract}
Based on treatment guidelines of crisis hypertension, emergency hypertensive treatment uses parenteral antihypertensive whereas urgency hypertensive uses oral antihypertensive. The goal is to achieve a drop in Mean Arterial Pressure (MAP) below 25\% and systolic/diastolic blood pressure (SBP/DBP) below or equal to 160/100 $\mathrm{mmHg}$. This study aimed to describe the decrease in MAP and SBP/DBP after 24 hours of oral amlodipine administration with various combinations in patients with crisis hypertension. This research was an observational research with cross-sectional design which was descriptive. Data collection was done retrospectively based on medical record data of hypertensive crisis patients that hospitalized at RSUD Sultan Syarif Mohamad Alkadrie Pontianak City from January 2016 until December 2017. The samples obtained were 38 patients. Results from the study showed that emergency hypertension patients who used oral amlodipine with other antihypertensive combinations had 24-hour MAP values of $24 \%$ and some emergency hypertension patients showed a MAP attainment of $32 \%$ with decreased SBP/DBP after 24 hours reached under 160/100 mmHg. The use of oral amlodipine amlodipine with other antihypertensive combinations in urgency hypertensive patients showed an achievement of 20 $23 \%$ reduction in MAP with decreased SBP/DBP after 24 hours under 160/100 $\mathrm{mmHg}$. The use of oral amlodipine with other antihypertensive combinations in emergency hypertensive patients did not show a desirable reduction in MAP. Treatment of urgency hypertensive by using oral amlodipine with various combinations of other antihypertensive therapies showed a decrease in MAP according to crisis hypertension treatment guidelines.
\end{abstract}

Keywords: Amlodipine, blood pressure, hypertensive crises, mean arterial pressure

Korespondensi: Dr. Nurmainah, MM., Apt., Program Studi Farmasi, Fakultas Kedokteran, Universitas Tanjungpura, Pontianak, Kalimantan Barat 78115, Indonesia, email: nurmainah@pharm.untan.ac.id

Naskah diterima: 3 Mei 2018, Diterima untuk diterbitkan: 15 Agustus 2018, Diterbitkan: 1 September 2018 


\section{Pendahuluan}

Hipertensi krisis merupakan suatu peningkatan akut pada tekanan darah sistolik (TDS) dan tekanan darah diastolik (TTD) di atas 180/120 mmHg. ${ }^{1}$ Berdasarkan pada ada atau tidaknya kerusakan pada organ target, hipertensi krisis dibedakan menjadi hipertensi emergensi dan hipertensi urgensi. ${ }^{2}$ Hipertensi emergensi ditandai dengan peningkatan TDS di atas 180 $\mathrm{mmHg}$ dan TDD di atas $120 \mathrm{mmHg}$ secara mendadak disertai dengan kerusakan organ target. ${ }^{1}$ Kerusakan organ yang terjadi pada hipertensi emergensi berupa perubahan status mental (ensefalopati), strok, gagal jantung, angina, edema paru, serangan jantung, aneurisma, dan eklampsia. ${ }^{3}$

Berdasarkan pedoman pengobatan hipertensi krisis, ada perbedaan pemilihan antihipertensi untuk pengobatan hipertensi emergensi dan hipertensi urgensi. Pengobatan dari hipertensi emergensi adalah menggunakan antihipertensi parenteral, yaitu seperti golongan beta bloker (esmolol), golongan Calcium Channel Blocker /CCB (nikardipin atau klevidipin), serta nitrat. Berbeda halnya dengan hipertensi emergensi, manajemen pengobatan hipertensi urgensi cukup dengan menggunakan antihipertensi oral. Antihipertensi yang dapat digunakan untuk mengatasi hipertensi urgensi adalah golongan beta bloker (labetalol) atau golongan central alpha-2 agonist (klonidin)., ${ }^{1,2,4}$

Target terapi yang harus dicapai pada pasien hipertensi emergensi adalah terjadinya penurunan rerata tekanan arteri atau Mean Arterial Pressure (MAP) dan tekanan darah pasien selama 1 jam, 2-6 jam berikutnya, dan 24 jam setelah pemberian antihipertensi. Pemberian antihipertensi parenteral selama 1 jam diharapkan dapat memberikan penurunan MAP sebesar $10 \%$ diikuti penurunan MAP mencapai $15 \%$ pada saat 2-3 jam berikutnya. Selanjutnya pada saat 24 jam, penurunan MAP mencapai $20-25 \%$ atau penurunan tekanan darah mencapai di bawah 160/110 mmHg. Di sisi lain, target terapi hipertensi urgensi adalah tercapainya penurunan MAP dalam waktu 24 jam sebesar $20-25 \%$ atau penurunan TDS/ TDD hingga $<160 / 110$ mmHg. ${ }^{1,4}$

Rumah Sakit Umum Daerah (RSUD) Sultan Syarif Mohamad Alkadrie Kota Pontianak menggunakan antihipertensi golongan CCB dalam bentuk oral yaitu amlodipin dengan berbagai kombinasi antihipertensi lainnya di dalam penanganan hipertensi krisis, baik hipertensi emergensi maupun urgensi, yang artinya tidak ada perbedaan dalam pemilihan rute penggunaan amlodipin untuk pengobatan kedua jenis hipertensi tersebut. Adanya perbedaan dalam manajemen pengobatan pada pedoman pengobatan hipertensi krisis dengan tata laksana pengobatan hipertensi krisis di RSUD Sultan Syarif Mohamad Alkadrie Kota Pontianak menjadi latar belakang penelitian ini dilakukan. Penelitian ini bertujuan untuk mendeskripsikan pencapaian dari penurunan MAP serta TDS/TDD pada pasien hipertensi krisis setelah pemberian tablet amlodipin dengan berbagai kombinasi antihipertensi lainnya setelah 24 jam.

\section{Metode}

Penelitian dilakukan menggunakan metode observasional dengan rancangan penelitian potong lintang (cross-sectional) yang bersifat deskriptif. Data yang diambil merupakan data retrospektif berupa data rekam medis pasien hipertensi krisis rawat inap di RSUD Sultan Syarif Mohamad Alkadrie Kota Pontianak periode Januari 2016 hingga Desember 2017. Jumlah subjek penelitian adalah sebanyak 38 subjek yang terdiri dari 17 pasien hipertensi emergensi dan 21 pasien hipertensi urgensi yang memenuhi kriteria inklusi.

Penelitian ini telah mendapatkan kelaikan etik dari Komisi Etik Penelitian Fakultas Kedokteran Universitas Tanjungpura dengan nomor 1051/UN22.9/DL/2018. Pengumpulan data dilakukan dengan menggunakan teknik 
purposive sampling. Kriteria inklusi antara lain pasien yang terdiagnosis hipertensi emergensi dan hipertensi urgensi, pasien hipertensi krisis dengan usia $\geq 40$ tahun, pasien yang menerima terapi antihipertensi golongan CCB. Kriteria eksklusi yaitu pasien hipertensi dengan data rekam medis yang tidak lengkap, pasien yang pindah atau dirujuk ke rumah sakit lain, dan pasien meninggal dunia. Data dianalisis secara deskriptif dan diolah dengan Microsoft Excel.

\section{Hasil}

Berdasarkan Tabel 1, diketahui bahwa pasien hipertensi krisis di instalasi rawat inap RSUD Sultan Syarif Mohamad Alkadrie Kota Pontianak pada periode Januari 2016 sampai dengan Desember 2017 dominan berada pada rentang usia $\geq 40-59$ tahun. Pasien berusia $\geq 40-59$ tahun yang mengalami hipertensi emergensi dan hipertensi urgensi secara berturut-turut sebanyak 36,84\% dan 31,58\%. Perempuan cenderung mengalami hipertensi krisis, dengan jumlah penderita perempuan pada hipertensi emergensi sebanyak $23,68 \%$ dan hipertensi urgensi 44,74\%. Denyut nadi pada hipertensi krisis pada umumnya normal (70-80 kali per menit) baik pada hipertensi emergensi maupun urgensi masing-masing adalah sebesar $42,11 \%$. Antihipertensi yang digunakan untuk mengatasi hipertensi krisis pada umumnya amlodipin dengan kombinasi 1 (satu) antihipertensi lainnya. Pasien hipertensi emergensi dan pasien hipertensi urgensi yang menggunakan amlodipin dengan kombinasi 1 (satu) antihipertensi secara berturut-turut adalah sebanyak $34,21 \%$ dan $42,11 \%$. Pasien hipertensi krisis pada umumnya masuk rumah sakit tidak memiliki riwayat penyakit kardiovaskular baik pada pasien hipertensi emergensi (36,84\%) maupun hipertensi urgensi (50\%).

Berdasarkan Tabel 2, dapat dilihat mengenai penanganan pengobatan hipertensi emergensi dan urgensi menggunakan amlodipin dengan kombinasi terapi dari 1 (satu) dan $\geq 2$ (dua) antihipertensi. Pasien hipertensi emergensi yang menggunakan amlodipin oral dengan

Tabel 1 Karakteristik Subjek Penelitian $(\mathbf{n}=38)$

\begin{tabular}{|c|c|c|c|c|}
\hline \multirow{2}{*}{ Karakteristik } & \multicolumn{2}{|c|}{ Hipertensi Emergensi } & \multicolumn{2}{|c|}{ Hipertensi Urgensi } \\
\hline & Jumlah & Persentase (\%) & Jumlah & Persentase (\%) \\
\hline \multicolumn{5}{|l|}{ Usia } \\
\hline$\geq 40-59$ & 14 & 36,84 & 12 & 31,58 \\
\hline$\geq 60$ & 3 & 7,9 & 9 & 23,68 \\
\hline \multicolumn{5}{|l|}{ Jenis Kelamin } \\
\hline Laki-Laki & 8 & 21,05 & 4 & 10,53 \\
\hline Perempuan & 9 & 23,68 & 17 & 44,74 \\
\hline \multicolumn{5}{|l|}{ Denyut Nadi } \\
\hline 70-80 kali per menit (normal) & 16 & 42,11 & 16 & 42,11 \\
\hline$>100$ kali per menit & 1 & 2,63 & 5 & 13,15 \\
\hline \multicolumn{5}{|l|}{ Regimen Terapi } \\
\hline Amlodipin $+1 \mathrm{AH}$ & 13 & 34,21 & 16 & 42,11 \\
\hline Amlodipin $+\geq 2$ AH & 4 & 10,53 & 5 & 13,15 \\
\hline \multicolumn{5}{|l|}{ Riwayat Penyakit Kardiovaskular } \\
\hline Strok & 1 & 2,63 & 1 & 2,63 \\
\hline Jantung & 2 & 5,27 & 1 & 2,63 \\
\hline Tidak memiliki riwayat kardiovaskular & 14 & 36,84 & 19 & 50,00 \\
\hline
\end{tabular}


Tabel 2 Profil Nilai Mean Arterial Pressure Pasien Hipertensi Krisis pada Saat Masuk Rumah Sakit dan Setelah 24 Jam Pemberian Amlodipin dengan Kombinasi Antihipertensi Lainnya $(\mathbf{n}=\mathbf{3 8})$

\begin{tabular}{|c|c|c|c|c|c|c|}
\hline \multirow{2}{*}{$\begin{array}{c}\text { Kategori } \\
\text { Hipertensi Krisis }\end{array}$} & \multirow{2}{*}{ Jumlah } & \multicolumn{2}{|c|}{$\begin{array}{c}\text { Nilai MAP } \\
\text { Pasien pada Saat } \\
\text { Masuk Rumah Sakit }\end{array}$} & \multicolumn{2}{|c|}{$\begin{array}{l}\text { Nilai MAP Pasien } \\
\text { Setelah } 24 \text { jam } \\
\text { Pemberian } \\
\text { Antihipertensi }\end{array}$} & \multirow{2}{*}{$\begin{array}{c}\text { Persentase } \\
\text { Pencapaian } \\
\text { Nilai MAP } \\
\text { Setelah 24 Jam } \\
(\%)\end{array}$} \\
\hline & & $\begin{array}{l}\text { Rata-Rata } \\
\text { Nilai MAP } \\
(\mathbf{m m H g})\end{array}$ & $\begin{array}{l}\text { Nilai Min- } \\
\text { Maks MAP } \\
\text { (mmHg) }\end{array}$ & $\begin{array}{l}\text { Rata-Rata } \\
\text { Nilai MAP } \\
\text { (mmHg) }\end{array}$ & $\begin{array}{l}\text { Nilai Min- } \\
\text { Maks MAP } \\
(\mathbf{m m H g})\end{array}$ & \\
\hline \multicolumn{7}{|l|}{ Hipertensi Emergensi } \\
\hline Amlodipin +1 AH & 13 & 145 & $128-180$ & 110 & $83-127$ & 24 \\
\hline Amlodipin $+\geq 2 \mathrm{AH}$ & 4 & 158 & $147-167$ & 108 & $77-140$ & 32 \\
\hline \multicolumn{7}{|l|}{ Hipertensi Urgensi } \\
\hline Amlodipin +1 AH & 16 & 143 & $113-193$ & 110 & $73-140$ & 23 \\
\hline Amlodipin $+\geq 2 \mathrm{AH}$ & 5 & 143 & $123-170$ & 114 & $90-133$ & 20 \\
\hline
\end{tabular}

kombinasi terapi 1 (satu) antihipertensi lain setelah 24 jam menunjukkan pencapaian MAP mencapai di bawah 25\%. Namun demikian, beberapa pasien yang menggunakan amlodipin dengan tambahan $\geq 2$ antihipertensi lainnya menunjukkan penurunan MAP-nya belum tercapai dengan optimal, yaitu sebesar 32\%.

Berbeda halnya dengan pasien hipertensi urgensi, penggunaan dari amlodipin dengan kombinasi 1 (satu) dan $\geq 2$ (dua) antihipertensi lainnya menunjukkan pencapaian MAP yang sesuai dengan yang diharapkan, yaitu masingmasing sebesar 23\% dan 20\%. Hal ini berarti penurunan MAP pada pasien urgensi yang menggunakan amlodipin dengan kombinasi antihipertensi lainnya mencapai di bawah 25\%. Pencapaian penurunan tekanan darah setelah 24 jam baik pada pasien emergensi dan urgensi menujukkan TDS/TDD-nya mencapai sekitar $160 / 100 \mathrm{mmHg}$ atau di bawah 160/100 $\mathrm{mmHg}$. Data secara lengkap dapat dilihat pada Tabel 3.

Tabel 3 Profil Tekanan Darah Pasien Hipertensi Krisis pada Saat Masuk Rumah Sakit dan Setelah 24 Jam Pemberian Amlodipin dengan Kombinasi Antihipertensi Lainnya (n=38)

\begin{tabular}{|c|c|c|c|c|c|c|c|}
\hline \multirow[b]{2}{*}{$\begin{array}{c}\text { Kategori } \\
\text { Hipertensi Krisis }\end{array}$} & \multirow[b]{2}{*}{ Jumlah } & \multicolumn{3}{|c|}{$\begin{array}{c}\text { Kondisi Tekanan Darah } \\
\text { Pasien pada Saat } \\
\text { Masuk Rumah Sakit }\end{array}$} & \multicolumn{3}{|c|}{$\begin{array}{l}\text { Kondisi Tekanan Darah } \\
\text { Pasien Setelah } 24 \text { jam } \\
\text { Pemberian Antihipertensi }\end{array}$} \\
\hline & & $\begin{array}{c}\text { Rata- } \\
\text { Rata } \\
\text { TDS/ } \\
\text { TDD } \\
\text { (mmHg) }\end{array}$ & $\begin{array}{c}\text { Nilai } \\
\text { Min- } \\
\text { Maks } \\
\text { TDS } \\
\text { (mmHg) }\end{array}$ & $\begin{array}{c}\text { Nilai } \\
\text { Min- } \\
\text { Maks } \\
\text { TDD } \\
\text { (mmHg) }\end{array}$ & $\begin{array}{c}\text { Rata- } \\
\text { Rata } \\
\text { TDS/ } \\
\text { TDD } \\
\text { (mmHg) }\end{array}$ & $\begin{array}{c}\text { Nilai } \\
\text { Min- } \\
\text { Maks } \\
\text { TDS } \\
\text { (mmHg) }\end{array}$ & $\begin{array}{c}\text { Nilai } \\
\text { Min- } \\
\text { Maks } \\
\text { TDD } \\
\text { (mmHg) }\end{array}$ \\
\hline \multicolumn{8}{|l|}{ Hipertensi Emergensi } \\
\hline Amlodipin + $1 \mathrm{AH}$ & 13 & $209 / 113$ & $185-240$ & $100-150$ & $151 / 90$ & $110-180$ & $70-100$ \\
\hline Amlodipin $+\geq 2 \mathrm{AH}$ & 4 & $203 / 135$ & $190-220$ & $120-140$ & $140 / 93$ & $90-180$ & $70-120$ \\
\hline \multicolumn{8}{|l|}{ Hipertensi Urgensi } \\
\hline Amlodipin + $1 \mathrm{AH}$ & 16 & $202 / 113$ & $180-240$ & $80-170$ & $150 / 90$ & $100-220$ & $80-100$ \\
\hline Amlodipin $+\geq 2 \mathrm{AH}$ & 5 & $202 / 114$ & $190-230$ & $90-140$ & $162 / 90$ & $130-200$ & $70-100$ \\
\hline
\end{tabular}




\section{Pembahasan}

Karakteristik subjek penelitian

Usia merupakan faktor risiko untuk terjadinya hipertensi baik hipertensi emergensi maupun urgensi. Mula dirasakannya gejala hipertensi yaitu pada saat berusia di atas 45 tahun. ${ }^{6}$ Ketika usia di atas 45 tahun, mulai terjadi penurunan fungsi endotelium. Endotelium memiliki fungsi untuk menjaga elastisitas dan struktur dari pembuluh darah. ${ }^{7}$ Perubahan struktur pada pembuluh darah besar menyebabkan lumen menjadi lebih sempit dan dinding pembuluh darah menjadi lebih kaku. Tekanan darah yang meningkat yang diakibatkan berkurangnya kelenturan dari pembuluh darah besar dapat menyebabkan beberapa perubahan fisiologis seperti peningkatan resistensi perifer, elastisitas arteri, dan aktivitas simpatis. ${ }^{8}$

Hipertensi krisis dominan terjadi pada perempuan disebabkan adanya perubahan hormon. Sebuah hasil penelitian menunjukkan bahwa pasien perempuan yang mengalami hipertensi emergensi maupun urgensi berada pada rentang umur menopause, yaitu ketika berusia sekitar 50 tahun. Setelah menopause, pada tubuh perempuan terjadi suatu perubahan hormonal, yaitu penurunan perbandingan estrogen dan androgen. Penurunan estrogen menyebabkan peningkatan pelepasan renin dan memicu terjadi peningkatan tekanan darah. ${ }^{9}$ Mekanisme dari pelepasan renin merangsang pembentukan angiotensin I yang dibantu oleh angiotensin converting enzyme (ACE) diubah menjadi angiotensin II. Angiotensin II merupakan vasokonstriktor kuat yang dapat merangsang sekresi aldosteron oleh korteks adrenal. Hormon ini menyebabkan penurunan ekskresi air dan garam oleh ginjal. Kondisi ini dapat meningkatkan volume cairan ekstrasel dan meningkatkan tekanan arteri sehingga terjadi peningkatan tekanan pembuluh darah. ${ }^{10}$

Denyut nadi pasien hipertensi krisis, baik hipertensi emergensi maupun urgensi, pada umumnya normal (70-80 kali per menit)
Peningkatan kecepatan denyut nadi biasanya diiringi dengan penurunan volume sekuncup atau resistensi perifer total (RPT) yang dapat memiliki pengaruh atas terjadinya hipertensi. Peningkatan denyut nadi di atas 100 kali per menit menunjukkan bahwa terdapat kerusakan organ pada pasien hipertensi. ${ }^{4}$ Penggunaan antihipertensi untuk pengobatan hipertensi krisis lebih banyak menggunakan kombinasi terapi yaitu kombinasi amlodipin dengan 1 (satu) antihipertensi lainnya. Terapi untuk mengatasi hipertensi krisis harus memiliki awitan kerja yang cepat, mudah dititrasi, dan aman, ${ }^{11}$ mengingat tekanan darah yang harus diturunkan harus segera tercapai dalam waktu 24 jam dengan tujuan mencegah terjadinya kerusakan organ. ${ }^{3}$ Optimalisasi penggunaan kombinasi obat merupakan pilihan terapi yang tepat untuk pasien dengan hipertensi krisis. ${ }^{1}$ Salah satu faktor penyebab terjadinya hipertensi krisis yaitu riwayat penyakit pasien terutama penyakit kardiovaskular, namun pada penelitian ini umumnya pasien hipertensi krisis yang masuk rumah sakit tidak memiliki riwayat penyakit kardiovaskular sebelumnya, baik pasien penderita hipertensi emergensi maupun urgensi.

Profil nilai MAP dan tekanan darah pasien hipertensi krisis setelah 24 jam pemberian amlodipin dengan kombinasi antihipertensi lainnya

Penanganan dari hipertensi emergensi yang digunakan di rumah sakit adalah pemberian amlodipin dalam bentuk oral dengan disertai berbagai kombinasi antihipertensi lainnya. Penggunaan amlodipin dalam bentuk oral sebagai pengobatan hipertensi emergensi ini dikatakan belum tepat. Berdasarkan pedoman pengobatan hipertensi krisis, penanganan yang tepat untuk hipertensi emergensi adalah menggunakan antihipertensi rute parenteral. Hasil penelitian oleh Malesker dan Hilleman ${ }^{12}$ menyimpulkan bahwa penggunaan nikardipin intravena pada pasien hipertensi emergensi 
menunjukkan pencapaian penurunan tekanan darah secara optimal. Pencapaian penurunan tekanan darah optimal harus dilakukan secara cepat, reversibel, dan mudah dititrasi tanpa menimbulkan efek samping. Tujuannya untuk mencegah progresifitas dari kerusakan organ target. ${ }^{13}$ Kerusakan organ target yang dapat terjadi seperti hipertensi ensefalopati, diseksi aorta akut, eklamsi, dan infark miokard akut. ${ }^{1}$ Berdasarkan Tabel 2, beberapa pasien hipertensi emergensi yang mendapatkan amlodipin oral yang dikombinasikan antihipertensi lainnya belum menunjukkan penurunan MAP sesuai yang diharapkan. Nilai MAP yang diperoleh adalah sebesar $32 \%$ setelah 24 jam pemberian antihipertensi, sehingga potensi untuk terjadinya kerusakan organ masih tinggi.

Terdapat beberapa golongan antihipertensi yang dapat digunakan sebagai penanganan hipertensi emergensi dalam bentuk parenteral, antara lain golongan vasodilator (hidralazin, nitrogliserin, nitroprusid natrium), golongan CCB (klevidipin, nikardipin), golongan beta bloker(esmolol, labetalol, metoprolol), golongan angiotensin converting enzyme inhibitorl ACEI (enalaprilat). Pemilihan antihipertensi tersebut dilakukan dengan memperhatikan kondisi pasien hipertensi emergensi, seperti:

(1) ada atau tidaknya kerusakan organ target;

(2) farmakokinetik dan farmakodinamik; dan

(3) hemodinamik, efek samping obat, dan tekanan darah. ${ }^{4,5,14}$

Saat menggunakan antihipertensi secara parenteral pada pasien hipertensi emergensi, diharapkan agar dapat dilakukan pemantauan penurunan MAP dengan cermat setiap 1 jam, 2-3 jam, serta 24 jam berikutnya. Penurunan MAP pada 1 jam pertama diharapkan dapat mencapai $10 \%$, diikuti $2-3$ jam berikutnya sebesar $15 \%$, dan selanjutnya setelah 24 jam mencapai 20-25\%. Kondisi ini menunjukkan bahwa penurunan MAP pada pasien hipertensi emergensi harus dipantau secara bertahap. Tujuan pemantauan secara bertahap ini adalah untuk mencegah jantung dan pembuluh darah di otak tidak mengalami hipoperfusi. ${ }^{1}$ Namun demikian dari hasil penelitian ini, pengukuran TDS/TDD yang tercatat pada data rekam medis hanya dilakukan sebelum pemberian antihipertensi dan 24 jam setelah pemberian antihipertensi. Hasil pengukuran MAP yang diperoleh merupakan hasil MAP setelah 24 jam pemberian antihipertensi.

Pemilihan antihipertensi pada pasien hipertensi urgensi berbeda dengan hipertensi emergensi. Manajemen penanganan hipertensi urgensi yakni cukup dengan menggunakan antihipertensi secara oral. Berdasarkan hasil penelitian, diperoleh penggunaan amlodipin dengan kombinasi terapi antihipertensi lain menunjukkan penurunan MAP yaitu di bawah $25 \%$ dengan penurunan tekanan darah sekitar 160/110 mmHg setelah 24 jam pemberian antihipertensi. Hal ini sesuai dengan tata laksana pengobatan hipertensi urgensi dengan pencapaian penurunan MAP yang diperoleh selama 24 jam pertama yaitu berkisar $20-25 \%$ dan penurunan TDS/TDD mencapai 160/110 mmHg. ${ }^{14}$

Amlodipin merupakan CCB golongan dihidropiridin. Mula kerjanya lambat sehingga penurunan tekanan darah yang terjadi pun lambat. ${ }^{15}$ Hal ini tepat jika amlodipin diberikan untuk mengatasi hipertensi urgensi. Golongan CCB yang tepat diberikan kepada pasien hipertensi urgensi adalah nikardipin dengan dosis $30 \mathrm{mg}$ yang dapat diulang setiap 8 jam. Hal ini dikarenakan nikardipin memiliki efek antihipertensi yang cepat, stabil, dan memiliki efek yang minimal terhadap denyut jantung. ${ }^{13}$ Berdasarkan hasil penelitian yang dilakukan oleh Palupi et al., penggunaan nikardipin dapat menurunkan MAP tidak lebih dari 25\%. ${ }^{16}$

Antihipertensi lain yang dapat digunakan untuk mengatasi hipertensi urgensi adalah: 1) kaptopril dengan dosis awal sebesar $25 \mathrm{mg}$, dengan peningkatan dosis yang diberikan setelah 90-120 menit adalah 50-100 mg; 2) labetalol dengan dosis awal $200 \mathrm{mg}$ yang dapat diulang setiap 3-4 jam; dan 3) klonidin 
dengan dosis awal 0,1-0,2 mg diikuti dengan penggunaan dosis sebesar $0,05-0,1 \mathrm{mg}$ setiap jam sampai tercapainya tekanan darah yang diinginkan. Pemilihan antihipertensi yang tepat dapat menyebabkan tercapainya MAP yang diharapkan (mencapai kurang dari 25\%) dan mencegah terjadinya kerusakan organ target. ${ }^{1}$

Penelitian ini memiliki keterbatasan, di antaranya sulit untuk mendapatkan penurunan tekanan darah pada satu jam pertama setelah penggunaan obat antihipertensi terutama pada pasien hipertensi emergensi sebab data tersebut tidak dicantumkan pada rekam medis. Kedua, tidak dicantumkannya jenis kerusakan organ yang terjadi pada pasien hipertensi krisis.

\section{Simpulan}

Beberapa pasien hipertensi emergensi yang mendapat amlodipin oral dengan kombinasi antihipertensi lainnya menunjukkan penurunan MAP yang belum optimal yaitu sebesar $32 \%$. Berbeda halnya dengan pasien hipertensi urgensi, penggunaan amlodipin oral dengan kombinasi 1 (satu) dan $\geq 2$ (dua) antihipertensi menunjukkan penurunan MAP sebesar 20$23 \%$.

\section{Pendanaan}

Penelitian ini tidak didanai oleh sumber hibah manapun.

\section{Konflik Kepentingan}

Seluruh penulis menyatakan bahwa tidak terdapat konflik kepentingan dengan penelitian, kepenulisan (authorship), dan atau publikasi artikel ini.

\section{Daftar Pustaka}

1. Devicaesaria A. Hypertensive crises. Medicinus. 2014;27(3):9-24.

2. Wijaya I, Siregar P. Hypertensive crises in the adolescent: Evaluation of suspected renovascular hypertension. Acta Med Indones. 2013;45(1):49-54.

3. Herlianita R. Hypertensive crises. J Keperawatan. 2010;1(2):151-5. doi: 10.2 2219/jk.vli2.408

4. Varounis C, Katsi V, Nihoyannopoulos P, Lekakis J, Tousoulis D. Cardiovascular hypertensive crisis: Recent evidence and review of literature. Front Cardiovasc Med. 2017;3:51. doi: 10.3389/fcvm.2016.00051

5. Wani-Parekh P, Blanco-Garcia C, Mendez M, Mukherjee D. Guide of hypertensive crisis pharmacotherapy. Cardiovasc Hematol Disord Drug Targets. 2017;17(1): 52-7. doi: 10.2174/1871529X16666161220142020.

6. Nurmainah, Fudholi A, Dwiprahasto I. The persistence in the use of antihypertension as the predictor of incidence rate and hospitalization cost. J Manag Pharm Practice. 2014;4(4):200-6. doi: 10.22146/ jmpf.288

7. Virdis A, Ghiadoni L, Giannarelli C, Taddei. Endothelial dysfunction and vascular disease in later life. Maturitas. 2010;67(1):20-4. doi: 10.1016/j.maturita s.2010.04.006

8. Afrila N, Dewi AP, Erwin. Effectiveness of slow stroke back massage therapy combination and access to blood pressure decrease on hypertension patients. $\mathrm{J}$ Online Mahasiswa Program Studi Ilmu Keperawatan Universitas Riau. 2015;2(2): 1299-307.

9. Mutmainah N, Rahmawati M. Correlation between medication adherence with therapeutic outcome in hypertension patients at Rumah Sakit Daerah Surakarta in 2010. Pharmacon. 2010;11(2):51-6.

10. Sudayasa IP, Yasin ERS, Lianawati. The correlation of duration of use the oral contraceptive with hypertension. Prosiding Seminar Nasional Riset Kuantitatif Terapan 2017; 2017 April 8; Kendari, Indonesia. Indonesia: Universitas Halu Oleo; 2017. 
11. Lubis MDL. Recent management of perioperative hypertensive crises. Cermin Dunia Kedokteran. 2013;40(10):733-7.

12. Malesker MA, Hilleman DE. Intravenous labetalol compared with intravenous nicardipine in the management of hypertension in critically ill patients. J Crit Care. 2012;27(5):528.e7-14. doi: 10.101 6/j.j crc.2011.12.005.

13. Nurkhalis. Management of hypertensive crisis. Idea Nursing J. 2017;6(3):61-7.

14. Benken ST. Hypertensive emergencies; CCSAP 2018 book 1 medical issues in the ICU. Lenexa, Kansas, United States: American College of Clinical Pharmacy; 2018.

15. Departemen Farmakologi dan Terapeutik Fakultas Kedokteran Universitas Indonesia. Farmakologi dan terapi, $6^{\text {th }}$ Edition. Jakarta: Bagian Farmakologi Fakultas Kedokteran Universitas Indonesia; 2017.

16. Palupi PD, Rahmawati F, Probosuseno. Comparison of clinical response between nicardipine and diltiazem in hypertensive emergencies. J Manag Pharm Practice. 2015;5(3):172-7. doi: 10.22146/jmpf.206

(C) 2018 Angelina et al. The full terms of this license incorporate the Creative Common Attribution-Non Commercial License (https:// creativecommons. org/licenses/by-nc/4.0/). By accessing the work you hereby accept the terms. Non-commercial use of the work are permitted without any further permission, provided the work is properly attributed. 